Arch. Tierz., Dummerstorf 50 (2007) 5, 487-500

Research Institute for the Biology of Farm Animals Dummerstorf, Germany

DOROTHEA LÖSEL, ULRICH KÜCHENMEISTER, MARGITTA HARTUNG, GERD

NÜRNBERG, OLAF BELLMANN, and ELKE ALBRECHT

\title{
Non-invasive determination of body composition in pigs using a Norland XR-26 bone densitometer
}

\begin{abstract}
Non-invasive measurement of body composition provides advantages in growth studies compared to conventional techniques. The same individual can be measured several times, the measurement is faster, and the number of pigs required as well as the random effect of animal are reduced. The aim of the present study was to determine the composition of the half carcass and of the ham/shank region by a whole body dual-energy X-ray absorptiometry (DXA) scan of the live pig using a Norland XR-26. Accuracy and precision of DXA measurement were evaluated by regression analysis between DXA-derived values and chemical analysis as well as dissection. Pigs of different gender were used covering a wide range of body weights and body composition. Single regression analysis for lean and fat mass revealed a close relationship between half carcass DXA and chemical analysis $\left(\mathrm{R}^{2}=0.97\right.$ and $\mathrm{R}^{2}=0.91$, respectively) as well as dissection $\left(\mathrm{R}^{2}=0.99\right.$ and $\mathrm{R}^{2}=0.98$, respectively). The prediction accuracy $\left(\mathrm{R}^{2}\right)$ was lower for the tissue percentages than for the respective tissue masses. The relationship between live pig DXA and reference methods was close for dissected lean meat $\left(\mathrm{R}^{2}=\right.$ $0.90)$ and adipose tissue mass $\left(\mathrm{R}^{2}=0.93\right)$. For chemical lean and fat mass, $\mathrm{R}^{2}$ were slightly lower. Multiple regression analysis using one to four independent variables improved accuracy of prediction. The composition of ham and shank could be predicted more accurately than the half carcass composition.
\end{abstract}

Key Words: Dual-energy X-ray absorptiometry, pig, body composition, in vivo

\section{Zusammenfassung}

Titel der Arbeit: Nichtinvasive Bestimmung der Körperzusammensetzung von Schweinen mittels eines Norland XR-26 Knochendensitometers

Eine nichtinvasive Messung der Körperzusammensetzung bietet im Gegensatz zu konventionellen Methoden Vorteile für Wachstumsstudien. So kann dasselbe Tier mehrfach gemessen werden, die Messung erfolgt schneller, und die Anzahl der benötigten Tiere wird ebenso reduziert wie der zufällige Tiereffekt. Das Ziel der vorliegenden Untersuchung war es, unter Verwendung eines Norland XR-26 einen DXA-Scan am lebenden Schwein durchzuführen und daraus die Zusammensetzung der Schlachthälfte und der Schinken-/Eisbeinregion zu bestimmen. Um die Richtigkeit und Präzision der DXA-Messungen zu bewerten, wurden Regressionsanalysen zwischen den DXA-Werten und den Referenzwerten aus der chemischen Analyse und der Zerlegung angewendet. Es wurden Schweine unterschiedlichen Geschlechts verwendet, die ein breites Spektrum an Gewicht und Körperzusammensetzung abdeckten. Die einfache Regressionsanalyse für Mager- und Fettmasse zeigte eine enge Beziehung zwischen der DXA-Messung der Schlachthälfte und der chemischen Analyse $\left(\mathrm{R}^{2}=0,97 \mathrm{bzw}\right.$. $\mathrm{R}^{2}$ $=0,91)$, sowie der Zerlegung $\left(\mathrm{R}^{2}=0,99\right.$ bzw. $\left.\mathrm{R}^{2}=0,98\right)$. Die Vorhersagerichtigkeit $\left(\mathrm{R}^{2}\right)$ für die prozentualen Gewebeanteile war niedriger als für die entsprechenden Gewebemassen. Zwischen den DXA-Messungen lebender Schweine und den Referenzmethoden bestand eine enge Beziehung im Fall der zerlegten Magerfleischmasse $\left(\mathrm{R}^{2}=0,90\right)$ und Fettgewebemasse $\left(\mathrm{R}^{2}=0,93\right)$. Im Fall der chemischen Mager- und Fettmasse lag $\mathrm{R}^{2}$ etwas niedriger. In einer multiplen Regressionsanalyse wurden zwischen einer und vier unabhängigen Variablen verwendet, wodurch sich die Richtigkeit der Vorhersage verbesserte. Die Zusammensetzung von Schinken und Eisbein konnte mit höherer Richtigkeit vorhergesagt werden als die Zusammensetzung der Schlachthälfte.

Schlüsselwörter: Dualenergie-Röntgenabsorptiometrie, Schwein, Körperzusammensetzung, in vivo 


\section{Introduction}

Body composition is of great interest in animal science for the evaluation of feeding regimes, growth modifiers, keeping conditions and for genetic selection. The most widely used techniques are dissection and chemical analyses, but these are timeconsuming, expensive, and destructive. Conversely, a non-invasive technique allows measurements of the same individual at several times, e.g. before and after a treatment or during growth under differing conditions. This would also reduce the number of animals required. Dual-energy X-ray absorptiometry (DXA) is a non-invasive, accurate technique for the determination of bone mineral content and density, lean tissue and fat mass on the basis of whole body measurements. In numerous studies the applicability has been proven on pigs and a good precision has been shown (PINTAURO et al., 1996; KOO et al., 2002; CHAUHAN et al., 2003; SUSTER et al., 2003). Dual-energy X-ray absorptiometry has been applied in growth studies with pigs (MITCHELL and SCHOLZ, 1997; DUNSHEA et al., 2003; PURSEL et al., 2004; SUSTER et al., 2006a) and is also able to demonstrate genetic differences (MARCOUX et al., 2005; MITCHELL et al., 1998c).

The software of commercially available DXA devices has been generated for the accurate determination of human body composition. Therefore, the raw DXA output has to be adjusted for pigs (MITCHELL et al., 1996 a, b; MITCHELL et al., 1998 a, b; SUSTER et al., 2003). However, such calibration is necessary for each individual DXA device, because differences in the accuracy of DXA estimates of soft tissue composition exist among manufacturers and software versions (TOTHILL et al., 1999, 2001). Only few studies used live pigs for these evaluations (MITCHELL et al., 1996b, 2002; LUKASKI et al., 1999; SUSTER et al., 2003). None of these studies compared DXA results with chemically or dissection-derived composition of half carcass. SCHOLZ \& FÖRSTER (2006) were the first to predict the dissection-derived composition of half carcass by DXA scan of the live pig.

The aim of the present study was to determine the composition of the half carcass and of the ham/shank region by a whole body DXA scan of the live pig using a Norland XR-26. Accuracy and precision of DXA measurements were evaluated by regression analysis between DXA-derived values and chemical analysis as well as dissection.

Fattening pigs of different gender were used that covered a wide range of body weights and body composition.

\section{Animals}

\section{Material and methods}

A total of 50 German Landrace pigs (1 boar, 33 gilts, and 16 barrows) were obtained from the institute's swine facility. Since no gender effect on accuracy and precision has been observed (MARCOUX et al., 2003; PINTAURO et al., 1996; LUKASKI et al., 1999; SUSTER et al., 2003) we did not create separate prediction equations for gilts and barrows. Age ranged from 74 to 195 days. The pigs were selected for body weight to obtain an even distribution from 30 to $110 \mathrm{~kg}$ (Tab. 1). Feed was provided ad libitum. From day 70 to 133 of age, pigs received a diet containing $12.6 \mathrm{MJ} \mathrm{ME} / \mathrm{kg}$ and $17.0 \%$ crude protein. From day 134 diet contained $12.4 \mathrm{MJ} \mathrm{ME} / \mathrm{kg}$ and $15.5 \%$ crude protein. Prior to the scanning procedure, pigs were fasted for approximately 16 h. The pigs were transported to the institute's slaughterhouse where the DXA device was located in an adjoining room. Pigs were weighed on an electronic scale and 
sedated with a combined intramuscular injection of $10 \mathrm{mg}$ ketamine hydrochloride (Ursotamin $^{\circledR} 10 \%$, Serumwerk Bernburg AG, Bernburg, Germany) and $1.2 \mathrm{mg}$ azaperone (Stresnil ${ }^{\circledR}$, Janssen-Cilag GmbH, Neuss, Germany) per kg body weight. Subsequently, pigs were anesthetized with an intravenous infusion of $23 \mathrm{mg}$ ketamine hydrochloride and $2 \mathrm{mg}$ xylazine hydrochloride (Xylazin 2\% Riemser, Riemser Arzneimittel AG, Greifswald, Germany) per kg body weight. All animals were cared for and killed according to German rules and regulations for animal care. The experiment was approved by the institutional authorities and by the responsible office of the County of Mecklenburg-Vorpommern, Germany (Landesveterinär- und Lebensmitteluntersuchungsamt Mecklenburg-Vorpommern).

Table 1

Allocation of pigs to weight groups from 30 to $110 \mathrm{~kg}$, age range, and mean \pm standard deviation (Verteilung der verwendeten Schweine auf Gewichtsgruppen von 30 bis $110 \mathrm{~kg}$, Altersbereich und Mittelwerte \pm Standardabweichung)

\begin{tabular}{cccc}
\hline Weight group $(\mathrm{kg})$ & $\mathrm{n}=50$ & Weight range $(\mathrm{kg})$ & Age range $(\mathrm{d})$ \\
\hline $30-50$ & 12 & $31.6-48.0$ & $71-110$ \\
$50-70$ & 13 & $51.1-69.6$ & $89-159$ \\
$70-90$ & 12 & $71.1-88.4$ & $138-195$ \\
$90-110$ & 13 & $90.7-109.8$ & $143-195$ \\
Mean \pm SD & & $69.75 \pm 22.89$ & $140 \pm 31.6$ \\
\hline
\end{tabular}

\section{Dual-energy $X$-ray absorptiometry}

Animals were placed on the scanner's table in a prone position with the hind legs extended and slightly tied together while the front legs were positioned along the side but kept away from the body by two wedges of foam plastic. DXA scans were performed in duplicate without repositioning of the pigs between the two scans.

Body composition was measured with an XR-26 Bone Densitometer (Computer Software Version 2.5.3a, Norland Corporation, White Plains, NY, USA) in the whole body mode. This instrument utilizes a pencil-beam technology, scanning at crosssectional intervals of $13 \mathrm{~mm}$ with a scan speed of $180 \mathrm{~mm} / \mathrm{s}$. A dynamically changing samarium filtration system automatically optimizes the photon count rate for varying object thickness.

The software provides predetermined regions on the scan image for calculation of the composition of different parts of the body. From an additionally defined region that covered the whole body, the whole body bone mineral density (BMD), bone mineral content (BMC), bone area and length of the object, lean mass (LM), and fat mass (FM) were determined. The DXA-derived body weight (DXA BW) was calculated by summarizing BMC, LM, and FM. Lean percentage (\%LM) and fat percentage (\%FM) were calculated by dividing LM and FM by DXA BW, respectively. Fat-to-lean-ratio was calculated by dividing FM by LM. The leg region was redefined on the scan image before analysis. It started at the anterior end of the pelvic bone and ended at the distal end of the femur and thus corresponds to the ham plus shank from dissection. All traits were measured and calculated as described for the whole body.

After completion of the second scan, pigs were slaughtered and eviscerated. After $24 \mathrm{~h}$ chilling the right half carcasses were scanned in duplicate on the XR-26 device with the cut side down. As for the live pig, a whole body region was defined. The predetermined leg region could not be used for the half carcass. Therefore, an 
additional region was defined that covered the ham and shank. From both regions, traits were measured and calculated as described for the whole body.

\section{Chemical analysis}

Immediately after the DXA scan of the right half carcass, it was autoclaved, then ground and homogenized. Samples of the homogenate were analyzed for water/dry matter, fat, and ash according to standard methods (Association of Official Agricultural Chemists, 2000). Fat content was obtained in triplicates via the Soxhlet extraction method using petroleum ether as the solvent and determined gravimetrically after evaporating the extracting solvent and protein was calculated by difference (KUHN et al., 1994). Additionally, blood, internal organs, mesenteric fat, and leaf fat ("offal fraction") of each pig were pooled and analyzed for chemical composition as above for the carcass. Chemically-derived lean mass was calculated as the crude protein content plus water.

\section{Dissection}

Following a $24 \mathrm{~h}$ chilling, the left half carcass was dissected into primal cuts according to the German reference dissection method (SCHEPER and SCHOLZ, 1985). Then the main primal cuts (loin, shoulder, ham, belly, tenderloin) were separated into lean meat, subcutaneous fat, intermuscular fat, tendons and connective tissue, skin, and bone. Back fat and neck fat were separated into skin and adipose tissue. The composition of the remaining parts was estimated using multiple regression equations (BRANSCHEID et al., 1990; HÖRETH, 2005, personal communication). The tissue composition of the whole carcass was calculated by summarizing the respective measured and estimated components of the primal cuts. To avoid the influence of the person on dissection result, the main primal cuts were dissected by the same person.

Adipose tissue, lean meat, and the mixture of bone, tendons, and skin from the combined ham and hind shank were also chemically analyzed.

\section{Statistical evaluation}

Statistical analysis was performed using the SAS statistical software (Version 9.1, SAS Inst. Inc., Cary, NC). Values are given as mean \pm standard deviation unless stated otherwise.

Repeatability of the duplicate scans was expressed as intraclass correlation (IC) coefficient. It was calculated from the covariance parameters from variance analysis. Single regression analysis was used to determine the relationship between values measured by DXA and the corresponding values from carcass analysis (chemical and dissection). The value from carcass analysis was regarded as the dependent variable and the DXA determined value was considered to be the independent variable.

A stepwise regression procedure was used to obtain the best-fitting multiple regression equations. A significance level of $\mathrm{P}<0.05$ was set for variables staying in the equation. Potential independent variables for multiple regression were: BMD, BMC, LM, \%LM, FM, \%FM, area, length, DXA BW, fat-to-lean-ratio for whole body and leg region, respectively.

The accuracy of the carcass composition estimation by DXA measurements was evaluated by comparing the adjusted coefficients of determination $\left(\operatorname{adj} . \mathrm{R}^{2}\right)$ and standard errors of estimation (SEE = root mean square error). 
Results and discussion

Accuracy and precision of the Norland XR-26

The intraclass correlation (IC) coefficients were determined to test if two consecutive scans of the same animal yielded the same results and represent a measure for repeatability. The IC coefficients for the raw DXA output data (BMD, BMC, LM, and FM) from the half carcass scans were greater than 0.99 . The IC coefficients for the whole live animal were greater than 0.95 for all considered variables. The values were smaller than described by PINTAURO et al. (1996) for the Lunar DPX-L densitometer. Slightly smaller IC coefficients (0.93) were found for FM and BMD in the leg region of the live pig. The lower repeatability of the measurement in the leg region of the live pigs can be caused by the influence of gut content, by movement of the animal during the scan or by determination of the region of interest.

The accurate determination of body mass by DXA is of basic importance, especially if, like in our study, tissue percentages are calculated from tissue masses and the whole body mass. However, this is no guarantee for the correct differentiation of the bone, lean, and fat components, because one component could be overestimated at the expense of another component (ROUBENOFF et al., 1993). The mean DXA BW was $1 \%$ less than the mean scale weight. There was also a small difference between the scale weight and half carcass DXA BW (Tab. 2). This discrepancy seems to be due to a systemic bias of the technology rather than imprecision in scale weighing. A minor underestimation of DXA tissue mass also occurred in numerous studies (KOO et al., 2002; MITCHELL et al., 1996a, b; MITCHELL et al., 1998a, b, c). Nonetheless, there is a close relationship between live animal scale weight and DXA BW ( $r=0.999$; $\mathrm{P}<$ $0.001)$ as well as between half carcass scale weight and half carcass DXA BW ( $\mathrm{r}=$ 0.999; P < 0.001). This has also been observed in other studies (MITCHELL et al., 1996a; PINTAURO et al., 1996; LUKASKI et al., 1999; CHAUHAN et al., 2003).

Table 2

Body composition of pigs $(n=50)$ from DXA of the live animal and the half carcass compared to chemical analysis and dissection of the half carcass. Values are means \pm SD, range in brackets. (Körperzusammensetzung der Schweine $(n=50)$ aus der DXA-Analyse des lebenden Tieres und der Schlachthälfte im Vergleich zur chemischen Analyse und Zerlegung der Schlachthälfte. Mittelwerte \pm Standardabweichung, Spannweite in Klammern).

\begin{tabular}{lcccc}
\hline & Chemical analysis & Dissection & DXA live animal & DXA half carcass \\
\hline Weight (kg) & & $25.41 \pm 8.96^{\S}$ & $69.05 \pm 22.72^{\dagger}$ & $25.07 \pm 8.97^{\dagger}$ \\
& & $(10.2-41.6)$ & $(31.0-108.1)$ & $(10.1-41.1)$ \\
Lean (g) & $18,953 \pm 5,806^{\ddagger}$ & $14,561 \pm 5,142$ & $52,942 \pm 13,837$ & $19,254 \pm 6,063$ \\
& $(8,514-30,240)$ & $(5,890-23,511)$ & $(26,561-78,501)$ & $(8,797-29,912)$ \\
Lean (\%) & $76.21 \pm 6.82$ & $56.18 \pm 2.82$ & $78.74 \pm 8.01$ & $78.25 \pm 5.70$ \\
& $(58.60-86.52)$ & $(48.51-61.69)$ & $(55.76-94.12)$ & $(62.38-88.94)$ \\
Fat (g) & $5,661 \pm 3,472$ & $6,091 \pm 2,966$ & $14,661 \pm 10,364$ & $5,120 \pm 3,092$ \\
& $(1,297-15,426)$ & $(1,740-14,208)$ & $(1,235-45,594)$ & $(967-14,326)$ \\
Fat (\%) & $20.67 \pm 6.78$ & $22.65 \pm 3.96$ & $19.17 \pm 7.99$ & $19.00 \pm 5.69$ \\
& $(10.54-38.10)$ & $(16.01-33.51)$ & $(3.98-42.16)$ & $(8.78-34.84)$ \\
\hline
\end{tabular}

${ }^{\S}$ Weight of half carcass

${ }^{\dagger}$ Calculated as sum of BMC, DXA LM, and DXA FM

${ }^{\ddagger}$ Calculated as sum of water plus protein 


\section{Half carcass scan}

The mean values for lean and fat contents obtained from DXA, chemical analysis, and dissection are shown in Table 2. Comparing the respective half carcass DXA values with the values from half carcass chemical analysis and half carcass dissection gives a good impression of the performance of the XR-26. Lean mass is defined by DXA as fat free, bone mineral free mass and was compared to chemical lean based on protein and water. Mean chemical lean mass was 1.59 \% less than half carcass DXA LM.

Lean mass from dissection, which corresponds to lean meat, was lowest because the skeletal muscle mass does not cover all of the protein and water existing in the body. The same observation was made by MARCOUX et al. $(2003,2005)$ and SUSTER et al. (2004) on pig carcasses and primal cuts. Consequently, the lean meat percentage from dissection (skeletal muscle) was lower (56.18 \%) than the lean percentage from half carcass DXA and chemical analysis (76.21 and $78.25 \%$, respectively), which were similar. The mean DXA FM in the half carcass was $9.5 \%$ less than that determined by chemical analysis. An underestimation of fat in the half carcass has also been observed by MITCHELL et al. (1998a, c; 2003) using pigs in a similar weight range as in the present study. As expected, the greatest fat mass was found by dissection because adipose tissue also contains water and protein.

Single regression analysis for lean mass (Tab. 3 ) revealed a close relationship between half carcass DXA and chemical analysis $\left(\mathrm{R}^{2}=0.97\right)$ as well as dissection $\left(\mathrm{R}^{2}=0.99\right)$.

Furthermore, half carcass DXA FM was strongly related to fat mass from chemical analysis $\left(\mathrm{R}^{2}=0.91\right)$ and adipose tissue from dissection $\left(\mathrm{R}^{2}=0.98\right)$. Generally, the prediction accuracy $\left(\mathrm{R}^{2}\right)$ was lower for the tissue percentages than for the respective tissue masses. The development of body composition during growth provides a possible explanation. The lean mass derived from the three methods increased with live weight, resulting in high correlations (data not shown). The $\mathrm{R}^{2}$ was similar for prediction of chemical lean and dissection lean mass. The $\mathrm{R}^{2}$ for lean meat percentage was lower probably because the lean meat percentage did not change with increasing live weight (Fig. 1a). Therefore, a close relationship between lean meat percentage and DXA \%LM is not possible. In contrast, chemical lean percentage decreased due to decreasing body water which is reflected in decreasing DXA \%LM.

Table 3

Relationships obtained by single regression between half carcass DXA and chemical analysis and dissection of the half carcass (Beziehungen nach der einfachen Regressionen zwischen der DXA-Messung der Schlachthälfte und der chemischen Analyse und Zerlegung der Schlachthälfte)

\begin{tabular}{lccc}
\hline $\begin{array}{l}\text { Dependent variable: } \\
\text { half carcass }\end{array}$ & $\begin{array}{c}\text { Independent variable of half } \\
\text { carcass DXA }\end{array}$ & adj. R & SEE \\
\hline Chemical analysis & & & \\
Lean (g) & LM & 0.97 & 1,029 \\
Lean (\%) & \%LM & 0.73 & 3.56 \\
Fat (g) & FM & 0.91 & 1,069 \\
Fat (\%) & \%FM & 0.74 & 3.49 \\
Dissection & & & \\
Lean meat (g) & LM & 0.99 & 567 \\
Lean meat (\%) & \%LM & 0.48 & 1.99 \\
Adipose tissue (g) & FM & 0.98 & 457 \\
Adipose tissue (\%) & \%FM & 0.89 & 1.29 \\
\hline
\end{tabular}


On the other hand, adipose tissue percentage was strongly related to DXA \%FM $\left(\mathrm{R}^{2}=\right.$ 0.89). Unlike lean tissue, the fat percentage increased over the live weight range independently of the method used (Fig. 1b). The fact, that dissection ignores the intramuscular fat while chemical analysis and DXA are supposed to detect the whole fat in the half carcass, seems to have no effect. A compensation probably occurred by the inclusion of water and protein in adipose tissue and the increasing fat content in adipose tissue at the expense of water as shown in Figure 2 for subcutaneous fat from ham and shank.
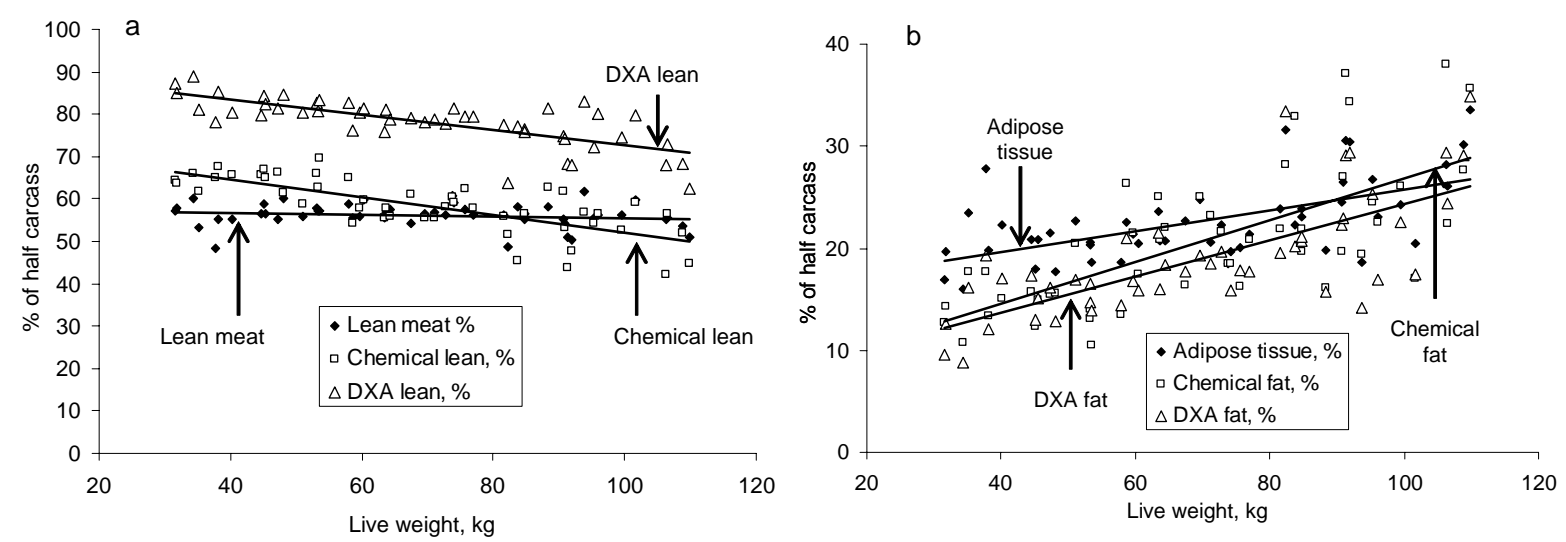

Fig. 1: Lean (a) and fat (b) percentage in the half carcass, measured by DXA, chemical analysis, and dissection. Values are plotted against live weight (Mageranteile (a) und Fettanteile (b) in der Schlachthälfte, gemessen mittels DXA, chemischer Analyse und Zerlegung. Die Werte sind gegen das Körpergewicht aufgetragen)

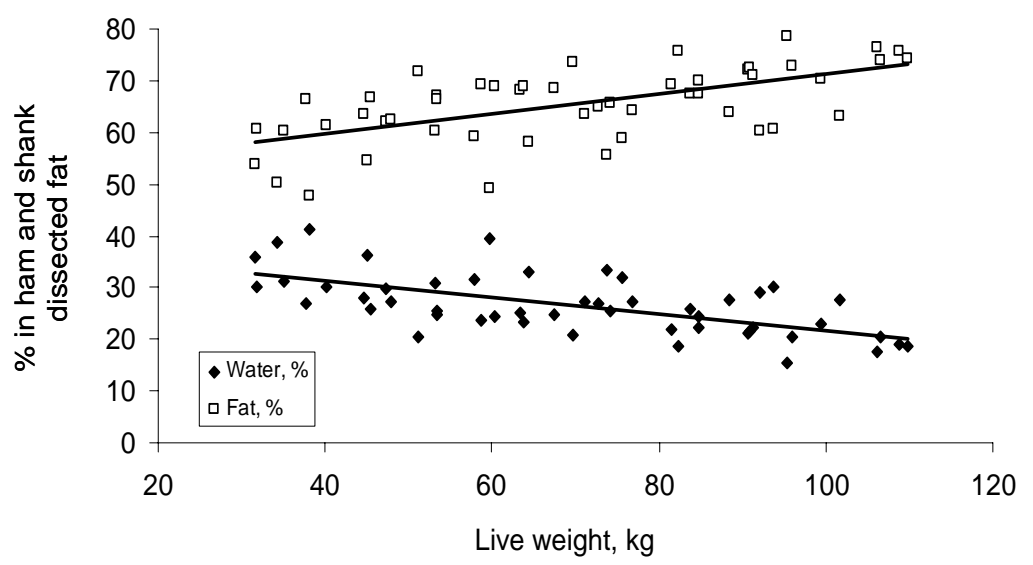

Fig. 2: Chemically-derived fat and water percentage in dissected subcutaneous and intermuscular fat of ham/shank. Values are plotted against live weight (Chemisch analysierte Fett- und Wasseranteile im subkutanen und intermuskulären Fett von Schinken und Eisbein. Die Werte sind gegen das Körpergewicht aufgetragen)

The effect of varying tissue hydration levels in growing animals has been discussed sufficiently (MITCHELL et al., 1998a, c; SUSTER et al., 2003, 2004; SCHOLZ et al., 2007). In brief, the function of DXA is based on the ratio of photon attenuation at the low energy level to attenuation observed at the higher energy. This ratio is called $\mathrm{R}$ value and is characteristic for each chemical element. Reference $\mathrm{R}$ values for pure fat and pure lean can be obtained by their theoretical chemical composition as well as by tissue phantoms. The composition of a bone-free pixel can be established from the measued $\mathrm{R}$ value and the assumed $\mathrm{R}$ values for the two respective components 
(PIETROBELLI et al., 1996). A deviation of the actual R value of lean, e.g. by higher water content, would cause errors in partitioning fat and lean components (PIETROBELLI et al., 1998; ROUBENOFF et al., 1993). In fact, the chemical protein to water ratio in the half carcass varied from 0.22 to 0.40 in the present study with individual differences, but a rising tendency with age.

In conclusion, there exists a close relationship between half carcass DXA and reference methods for body composition. Body composition from dissection was more accurately predicted by DXA measurement than body composition from chemical analysis with the exception of lean meat percentage.

\section{Live animal scan}

To predict half carcass composition from a DXA scan of the live animal, in a first step a single regression analysis was conducted with the DXA values from the whole body analysis as independent variables. In order to improve prediction accuracy a stepwise regression analysis was applied using DXA values from whole body and from the leg region as potential independent variables. We selected the legs as sub-region for two reasons. Firstly, it can be easily defined anatomically on the output image of the DXA software. Secondly, this region corresponds well to the ham and shank because no other primal cuts are located above or underneath and relatively few internal organs are included. The results are shown in Table 4.

Table 4

Relationships obtained by both single and multiple regression analysis between live animal DXA and chemical analysis and dissection of the half carcass (Beziehungen nach einfacher und multipler Regressionsanalyse zwischen der DXA-Messung des lebenden Tiers und der chemischen Analyse und Zerlegung der Schlachthälfte)

\begin{tabular}{|c|c|c|c|c|c|c|}
\hline \multirow[b]{2}{*}{$\begin{array}{l}\text { Dependent } \\
\text { variable: half } \\
\text { carcass } \\
\end{array}$} & \multicolumn{3}{|c|}{ Single regression } & \multicolumn{3}{|c|}{ Multiple regression } \\
\hline & $\begin{array}{c}\text { Independent } \\
\text { variable }\end{array}$ & adj. $\mathrm{R}^{2}$ & SEE & $\begin{array}{l}\text { Independent } \\
\text { variables }\end{array}$ & adj. $R^{2}$ & SEE \\
\hline \multicolumn{7}{|c|}{ Chemical analysis } \\
\hline Lean (g) & LM & 0.88 & 1,999 & $\begin{array}{l}\text { BMC, } \\
\text { legs LM, } \\
\text { LM }\end{array}$ & 0.95 & 1,313 \\
\hline Lean (\%) & $\% \mathrm{LM}$ & 0.60 & 4.33 & legs \%FM & 0.69 & 3.79 \\
\hline Fat (g) & FM & 0.83 & 1,432 & $\begin{array}{l}\text { legs FM, } \\
\text { DXA BW, } \\
\text { legs bone area }\end{array}$ & 0.90 & 1,122 \\
\hline Fat (\%) & $\% F M$ & 0.65 & 3.98 & legs \%FM & 0.70 & 3.70 \\
\hline \multicolumn{7}{|l|}{ Dissection } \\
\hline Lean meat (g) & LM & 0.90 & 1,663 & $\begin{array}{l}\text { DXA BW, } \\
\text { legs \%FM, } \\
\text { BMC }\end{array}$ & 0.98 & 760 \\
\hline Lean meat (\%) & $\% \mathrm{LM}$ & 0.26 & 2.44 & $\begin{array}{l}\text { legs fat-to-lean-ratio, } \\
\text { DXA legs mass }\end{array}$ & 0.57 & 1.84 \\
\hline $\begin{array}{l}\text { Adipose tissue } \\
\text { (g) }\end{array}$ & FM & 0.93 & 804 & $\begin{array}{l}\text { legs FM, } \\
\text { BMC, } \\
\text { FM }\end{array}$ & 0.98 & 442 \\
\hline $\begin{array}{l}\text { Adipose tissue } \\
(\%)\end{array}$ & $\% \mathrm{FM}$ & 0.71 & 2.14 & $\begin{array}{l}\text { legs fat-to-lean-ratio, } \\
\text { length, } \\
\% F M \text {, } \\
\text { fat-to-lean-ratio }\end{array}$ & 0.84 & 1.58 \\
\hline
\end{tabular}


The coefficients of determination for single regression were lower when derived from live pig DXA than those derived from half carcass DXA. This was expected, because the composition of the offal fraction was different from that of the half carcass. For example, the mean proportion of chemical fat in the offal fraction was $9.1 \pm 4.1 \%$, compared to $20.7 \pm 6.8 \%$ in the half carcass. As expected, both the fat percentage in the half carcass and fat percentage in the offal fraction increased with body weight. However, the fat percentages of these two fractions had only a weak relationship of $\mathrm{R}^{2}$ $=0.54$, which points to large individual differences among the pigs. Whether these differences were due to different amounts of water in the gastrointestinal tract or to different fills of the abdominal fat depots cannot be concluded from the existing data. Also, the water content in the gastrointestinal tract causes overestimation in the DXAderived lean mass (SUSTER et al., 2003). As the offal fraction accounted for $20 \%$ (in heavy pigs) to $30 \%$ (in light pigs) of live weight, this could be an important source of discrepancies between results derived from half carcass compared to live pigs. Another source of inaccuracy is the fact that pigs lying in the prone position are relatively high. It is well established, that tissue thickness has a significant effect in physical models (JEBB et al., 1995; LASKEY et al., 1992; TOTHILL et al., 1994). In vivo, this impact has not been confirmed. LUKASKI et al. (1999) compared whole body scans of pigs lying in the prone or side position and reported no significant effect of body thickness in the range of $16-28 \mathrm{~cm}$ on accuracy. Although the Norland XR-26 used in the present study features a dynamic filtration which compensates for thickness differences, the Operator's Guide notes that inaccuracies and imprecision may occur at tissue heights above $20 \mathrm{~cm}$.

The relationship between live pig DXA and reference methods was close for dissected lean meat $\left(\mathrm{R}^{2}=0.90\right)$ and adipose tissue mass $\left(\mathrm{R}^{2}=0.93\right)$. For chemical lean and fat mass, $\mathrm{R}^{2}$ were slightly lower. The relationship between DXA and reference method percentages, however, was weaker as has also been observed by SCHOLZ and FÖRSTER (2006) by comparing DXA measurement of live pigs with dissection of the half carcass. In the present study, prediction accuracy was satisfactory for dissectionderived fat percentage $\left(\mathrm{R}^{2}=0.71\right)$, moderate for chemical lean and fat percentage $\left(\mathrm{R}^{2}\right.$ $=0.60$ and 0.65 , respectively), but not sufficient to accurately predict lean meat percentage $\left(R^{2}=0.26\right)$.

Multiple regression analysis was used to detect the best fitting variables from DXA analysis for predicting half carcass composition. Stepwise procedure selected one to four independent variables. Variables from the leg region were frequently used, sometimes in addition to the respective variable from whole body DXA. For example, for the prediction of adipose tissue mass, FM of whole body, and FM of the legs region (legs FM) were selected. For both chemical lean and fat percentage, legs \%FM was the best predictor. As expected, prediction accuracy increased as observed in other studies (PINTAURO et al., 1996; SCHOLZ and FÖRSTER, 2006) and approximated results from half carcass DXA in the case of tissue masses (Tab. 4). However, accuracies of fat and lean percentage were only moderate $\left(\mathrm{R}^{2}=0.57\right.$ to 0.70$)$, with the exception of adipose tissue percentage $\left(\mathrm{R}^{2}=0.84\right)$. The relationship between the predicted results obtained by the multiple regression equations and the observed results of the reference methods are visualized in Figure 3 for fat. There was a close fit between observed and predicted dissection-derived fat mass. However, for fat 
percentage, there was still considerable deviation of the predicted from the observed values.
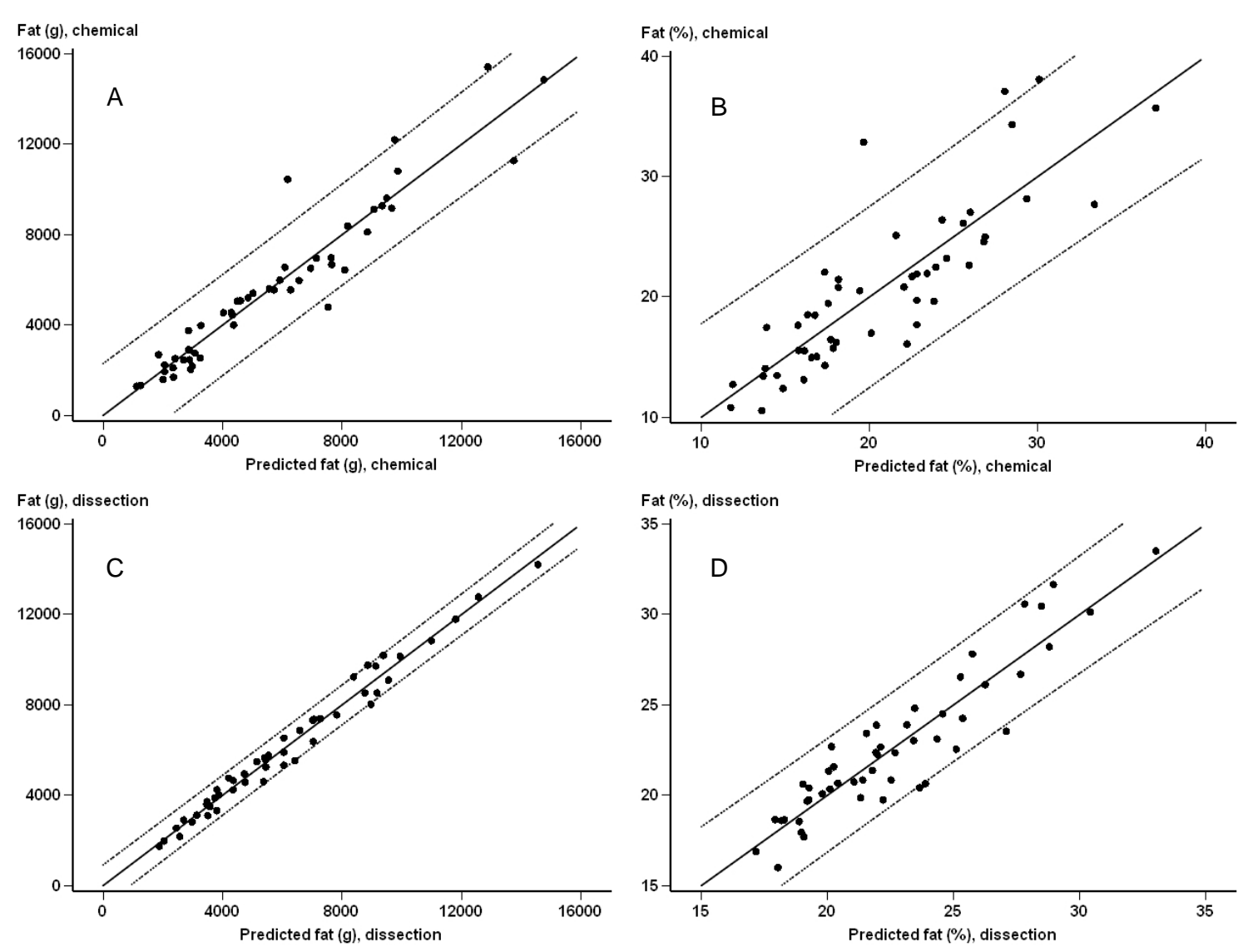

Fig. 3: Relationship between predicted values from multiple regression equations and observed values for chemically-derived fat mass and percent fat (A and B) or observed values for dissection-derived adipose tissue (C and D). Dotted lines represent the 95\% prediction interval (Beziehung zwischen vorhergesagten Werten aus der multiplen Regression und beobachteten Werten für chemische Fettmasse und chemischen Fettanteil (A und B) oder beobachteten Werten für Fettgewebemasse und -anteile aus der Zerlegung (C und D). Die gepunkteten Linien stellen das 95\% Vorhersageintervall dar)

As the leg region covers less internal organs than other regions on the scan image do, we tested if the composition of ham and shank could be predicted more accurately than the half carcass composition. The results of single and multiple regression analysis are shown in Table 5. Single regression analysis using DXA values from the leg region as independent variable resulted in coefficients of determination in the range of 0.90 to 0.93 for lean and fat masses and lower $\mathrm{R}^{2}(0.35$ to 0.71$)$ for percentages. The prediction of chemical lean and fat percentage from DXA analysis of ham in the present study revealed greater $\mathrm{R}^{2}$ than in a comparable study of MITCHELL et al. (1998 c). Obviously, the composition of primal cuts like ham and shank can be predicted more accurately by DXA live pig scans than the composition of the half carcass. This was shown by better prediction accuracy for chemically-derived lean percentage, fat mass, and fat percentage (Tab. 5). The use of stepwise regression analysis improved prediction accuracy for ham/shank considerably. Compared to the regression analysis for prediction of half carcass composition, $\mathrm{R}^{2}$ increased in the case of chemical analysis except for lean percentage. The reason for the better prediction accuracy can be partly explained by the underlying model of tissue composition in DXA devices. With only two X-ray energies, the lean and fat components can only be 
determined in areas that contain no bone. The proportions of fat and lean overlying and underlying bone must be estimated from neighboring pixels that contain no bone. Norland's fat distribution model for the whole body measurement assumes that fat is concentrated in the outer layers of the body and the proportion of lean is greater near the bone. For estimation of soft tissue composition in bone pixels, they use a weighted linear distribution model, with the pixels nearer the bone weighted more heavily in the regression (NORD and PAYNE, 1995). This model is more valid in the limbs than in the trunk, because in the limbs the amount and composition of the soft tissue can be assumed to be similar behind and in front of bone. In contrast, adipose tissue in the trunk is not uniformly distributed. Therefore, soft tissue composition in the trunk is more difficult to estimate. In addition, the internal algorithms are optimized for humans, but pigs have a differing body shape. As LUKASKI et al. (1999) pointed out, the fore and hind limbs contribute less to body weight in pigs than in humans. Thus, a relatively larger proportion of soft tissue is located in the trunk and susceptible to inaccuracies.

\section{Table 5}

Relationships obtained by both single and multiple regression analysis between live animal DXA and chemical analysis and dissection of the ham/shank (Beziehungen nach einfacher und multipler Regressionsanalyse zwischen der DXA-Messung des lebenden Tiers und der chemischen Analyse und Zerlegung von Schinken/Eisbein)

\begin{tabular}{|c|c|c|c|c|c|c|}
\hline \multirow[b]{2}{*}{$\begin{array}{l}\text { Dependent variable: } \\
\text { ham/shank }\end{array}$} & \multicolumn{3}{|c|}{ Single regression } & \multicolumn{3}{|c|}{ Multiple regression } \\
\hline & $\begin{array}{c}\text { Independent } \\
\text { variable }\end{array}$ & adj. $\mathrm{R}^{2}$ & SEE & $\begin{array}{l}\text { Independent } \\
\text { variables }\end{array}$ & adj. $\mathrm{R}^{2}$ & SEE \\
\hline \multicolumn{7}{|l|}{ Chemical analysis } \\
\hline Lean (g) & legs LM & 0.90 & 634 & $\begin{array}{l}\text { DXA BW, } \\
\text { legs \%FM, } \\
\text { legs BMD }\end{array}$ & 0.98 & 245 \\
\hline Lean (\%) & legs \%LM & 0.67 & 1.87 & legs \%FM & 0.67 & 1.86 \\
\hline Fat (g) & legs FM & 0.90 & 186 & $\begin{array}{l}\text { legs FM, } \\
\text { BMD, } \\
\text { legs BMD }\end{array}$ & 0.95 & 136 \\
\hline Fat (\%) & legs \%FM & 0.71 & 1.81 & $\begin{array}{l}\text { \%LM, } \\
\text { FM, } \\
\text { legs FM }\end{array}$ & 0.78 & 1.57 \\
\hline \multicolumn{7}{|l|}{ Dissection } \\
\hline Lean meat (g) & legs LM & 0.91 & 528 & $\begin{array}{l}\text { DXA BW, } \\
\text { legs \%FM, } \\
\text { legs DXA weight, } \\
\text { BMC }\end{array}$ & 0.98 & 242 \\
\hline Lean meat (\%) & legs \%LM & 0.35 & 2.17 & $\begin{array}{l}\text { legs \%LM, } \\
\text { LM }\end{array}$ & 0.59 & 1.73 \\
\hline Adipose tissue (g) & legs FM & 0.93 & 166 & $\begin{array}{l}\text { legs FM, } \\
\text { BMD, } \\
\text { legs BMD }\end{array}$ & 0.97 & 118 \\
\hline Adipose tissue (\%) & legs \%FM & 0.64 & 1.98 & $\begin{array}{l}\text { legs fat-to-lean } \\
\text { ratio, } \\
\text { LM, } \\
\text { \%LM }\end{array}$ & 0.74 & 1.67 \\
\hline
\end{tabular}

In studies on pigs where body composition is of interest, DXA is a useful technique. This technique can help in selection of animals for special purposes. In animal growth studies, DXA is able to detect changes in body composition by repeated measurements 
on the same individual. Some impacts on accuracy and precision of DXA are discussed in the previous section. However, the reference techniques are not devoid of being susceptible to inaccuracies either. Compared to the reference techniques, the main advantages of DXA are that it is non-invasive and much faster. Studies on changes in body composition during growth which use direct techniques like chemical analysis and dissection are based on slaughtering groups of pigs at various stages of age or weight. Using DXA would reduce the number of pigs required as well as the random effect of animal.

\section{Acknowledgements}

We thank Erika Nagel for help with the DXA measurements, Ilse Grünwald, Jörg Petschow, and Christian Alm for slaughtering and dissecting the pigs, and Heidrun Peters and Ursula Bretschneider for chemical analysis.

\section{References}

ASSOCIATION OF OFFICIAL AGRICULTURAL CHEMISTS:

Official methods of analysis. 12th ed. AOAC, Washington, DC. 2000.

BRANSCHEID, W.; DOBROWOLSKI, A.; SACK, E.:

Vereinfachung der EG-Referenzmethode für die grobgewebliche Vollzerlegung von Schweineschlachtkörpern. Fleischwirtsch. 70 (1990), 550-553

CHAUHAN, S.; KOO, W. W. K.; HAMMAMI, M.; HOCKMAN, E. M.:

Fan Beam Dual Energy X-Ray Absorptiometry Body Composition Measurements in Piglets. J. Am. Coll. Nutr. 22 (2003), 408-414

DUNSHEA, F. R.; SUSTER, D.; KERTON, D. J.; LEURY, B. J.:

Exogenous porcine somatotropin administered to neonatal pigs at high doses can alter lifetime fat but not lean tissue deposition. Br. J. Nutr. 89 (2003), 795-801

JEBB, S. A.; GOLDBERG, G. R.; JENNINGS, G.; ELIA, M.:

Dual-energy X-ray absorptiometry measurements of body composition: effects of depth and tissue thickness, including comparisons with direct analysis. Clin. Sci. 88 (1995), 319-324

KOO, W. W. K.; HAMMAMI, M.; HOCKMAN, E. M.:

Use of Fan Beam Dual Energy X-Ray Absorptiometry to Measure Body Composition of Piglets. J. Nutr. 132 (2002), 1380-1383

KUHN, G.; ENDER, K.; NÜRNBERG, K.:

Influence of recombinant porcine somatotropin (rpST) on the chemical composition of the edible whole body and individual body fractions in pigs. Arch. Tierz., Dummerstorf 37 (1994), 623-631

LASKEY, M. A.; LYTTLE, K. D.; FLAXMAN, M. E.; BARBER, R. W.:

The influence of tissue depth and composition on the performance of the Lunar dual energy X-ray absorptiometer whole-body scanning mode. Eur. J. Clin. Nutr. 46 (1992), 39-45

LUKASKI, H. C.; MARCHELLO, M. J.; HALL, C. B.; SCHAFER, D. M.; SIDERS, W. A.:

Soft tissue composition of pigs measured with dual X-ray absorptiometry: comparison with chemical analyses and effects of carcass thicknesses. Nutrition 15 (1999), 697-703

MARCOUX, M.; BERNIER, J. F.; POMAR, C.:

Estimation of Canadian and European lean yields and composition of pig carcasses by dual-energy Xray absorptiometry. Meat Science 63 (2003), 359-365

MARCOUX, M.; FAUCITANO, L.; POMAR, C.:

The accuracy of predicting carcass composition of three different pig genetic lines by dual-energy X-ray absorptiometry. Meat Science 70 (2005), 655-663

MITCHELL, A. D.; CONWAY, J.M.; POTTS, W.J.:

Body composition analysis of pigs by dual-energy X-ray absorptiometry. J. Anim. Sci. 74 (1996a), 2663-2671

MITCHELL, A. D.; CONWAY, J. M.; SCHOLZ, A. M.:

Incremental changes in total and regional body composition of growing pigs measured by dual-energy X-ray absorptiometry. Growth Dev. Aging 60 (1996b), 95-105

MITCHELL, A. D.; SCHOLZ, A. M.:

Dual-energy X-ray absorptiometry (DXA) analysis of growth and composition of pigs of different ryanodine receptor genotypes. Arch. Tierz., Dummerstorf 40 (1997) 1, 47-56 
MITCHELL, A. D., SCHOLZ, A. M., CONWAY, J. M.:

Body composition analysis of small pigs by dual-energy X-ray absorptiometry. J. Anim. Sci. 76 (1998a), 2392-2398

MITCHELL, A. D.; SCHOLZ, A. M.; CONWAY, J. M.:

Body composition analysis of pigs from 5 to $97 \mathrm{~kg}$ by dual energy X-ray absorptiometry. Appl. Radiat. Isot. 49 (1998b), 521-523

MITCHELL, A. D., SCHOLZ, A. M.; PURSEL, V.G.; EVOCK-CLOVER, C. M.:

Composition analysis of pork carcasses by dual-energy X-ray absorptiometry. J. Anim. Sci. 76 (1998c), 2104-2114

MITCHELL, A. D.; SCHOLZ, A. M.; PURSEL, V. G.:

Prediction of the in vivo Body Composition of Pigs Based on Cross-Sectional Region Analysis of Dual Energy X-Ray Absorptiometry (DXA) Scans. Arch. Tierz., Dummerstorf 45 (2002), 535-545

MITCHELL, A. D.; SCHOLZ, A. M.; PURSEL, V. G.:

Prediction of pork carcass composition based on cross-sectional region analysis of dual energy X-ray absorptiometry (DXA) scans. Meat Science 63 (2003), 265-271

NORD, R. H.; PAYNE, R. K.:

Body composition by dual-energy X-ray absorptiometry: a review of the technology. Asia Pacific J. Clin. Nutr. 4 (1994), 167-171

PIETROBELLI, A.; FORMICA, C.; WANG, Z.; HEYMSFIELD, S. B.:

Dual-energy X-ray absorptiometry body composition model: review of physical concepts. Am. J. Physiol. 271 (Endocrinol. Metab. 34) (1996), E941-E951

PIETROBELLI, A.; WANG, Z.; FORMICA, C.; HEYMSFIELD, S. B.:

Dual-energy X-ray absorptiometry: fat estimation errors due to variation in soft tissue hydration. Am. J. Physiol. 274 (Endocrinol. Metab. 37) (1998), E808-E816

PINTAURO, S. J.; NAGY, T. R.; DUTHIE, C. M.; GORAN, M. I.:

Cross-calibration of fat and lean measurements by dual-energy X-ray absorptiometry to pig carcass analysis in the pediatric body weight range. Am. J. Clin. Nutr. 63 (1996), 293-298

PURSEL, V. G.; MITCHELL, A. D.; BEE, G.; ELSASSER, T. H.; MCMURTRY, J. P.; WALL, R. J.;

COLEMAN, M. E.; SCHWARTZ, R. J.:

Growth and tissue accretion rates of swine expressing an insulin-like growth factor I transgene. Anim. Biotechnol. 15 (2004), 33-45

ROUBENOFF, R.; KEHAYIAS, J. J.; DAWSON-HUGHES, B.; HEYMSFIELD, S.B.:

Use of dual-energy X-ray absorptiometry in body-composition studies: not yet a "gold standard". Am. J. Clin. Nutr. 58 (1993), 589-591

SCHEPER, J.; SCHOLZ, W.:

DLG-Schnittführung für die Zerlegung der Schlachtkörper von Rind, Kalb, Schwein und Schaf. Arbeitsunterlagen DLG (1985), DLG-Verlag, Frankfurt/Main

SCHOLZ, A. M.; FÖRSTER, M.:

Genauigkeit der Dualenergie-Röntgenabsorptiometrie (DXA) zur Ermittlung der Körperzusammensetzung von Schweinen in vivo. Arch. Tierz., Dummerstorf 49 (2006), 462-476

SCHOLZ, A. M.; MITCHELL, A. D.; FÖRSTER, M.; PURSEL, V. G.:

Two-site evaluation of the relationship between in vivo and carcass dual energy X-ray absorptiometry (DXA) in pigs. Livest. Sci. 110 (2007), 1-11

SUSTER, D.; LEURY, B. J.; OSTROWSKA, E.; BUTLER, K. L.; KERTON, D. J.; WARK, J. D.; DUNSHEA, F. R.:

Accuracy of dual energy X-ray absorptiometry (DXA), weight and P2 back fat to predict whole body and carcass composition in pigs within and across experiments. Livest. Prod. Sc. 84 (2003), 231-242

SUSTER, D.; LEURY, B. J.; HOFMEYR, C. D.; D'SOUZA, D. N.; DUNSHEA, F. R.:

The accuracy of dual energy X-ray absorptiometry (DXA), weight, and P2 back fat to predict halfcarcass and primal-cut composition in pigs within and across research experiments. Austr. J. Agric. Res. 55 (2004), 973-982

SUSTER, D. ; LEURY, B. J.; KERTON, D. J.; DUNSHEA, F. R.:

Dual energy X-ray absorptiometry predicts the effects of dietary protein on body composition of pigs. Aust. J. Exp. Agric. 46 (2006), 1439-1445

TOTHILL, P.; AVENELL, A.; LOVE, J.; REID, D. M.:

Comparisons between Hologic, Lunar and Norland dual-energy X-ray absorptiometers and other techniques used for whole-body soft tissue measurements. Eur. J. Clin. Nutr. 48 (1994), 781-794

TOTHILL, P.; LASKEY, M. A.; ORPHANIDOU, C. I.; VAN WIJK, M.:

Anomalies in dual energy X-ray absorptiometry measurements of total-body bone mineral during weight change using Lunar, Hologic and Norland instruments. Br. J. Radiol. 72 (1999), 661-669 
TOTHILL, P.; HANNAN, W. J.; WILKINSON, S.:

Comparisons between a pencil beam and two fan beam dual energy X-ray absorptiometers used for measuring total body bone and soft tissue. Br. J. Radiol. 74 (2001), 166-176

Received: 2007-08-10

Accepted: 2007-09-06

Authors' addresses

Dr. DOROTHEA LÖSEL, Research Unit Muscle Biology and Growth

(E-Mail: loesel@fbn-dummerstorf.de)

Dr. ULRICH KÜCHENMEISTER, Research Unit Muscle Biology and Growth

(E-Mail: kuechenm@fbn-dummerstorf.de)

Dr. MARGITTA HARTUNG, Research Unit Muscle Biology and Growth

(E-Mail: hartung@fbn-dummerstorf.de)

Dr. GERD NÜRNBERG, Research Unit Genetics and Biometry

(E-Mail: gnuernbg@fbn-dummerstorf.de)

Dr. OLAF BELLMANN

(E-Mail: bellmann@fbn-dummerstorf.de)

Dr. ELKE ALBRECHT*, Research Unit Muscle Biology and Growth

(E-Mail: elke.albrecht@fbn-dummerstorf.de)

Research Institute for the Biology of Farm Animals,

Wilhelm-Stahl-Allee 2

18196 DUMMERSTORF

GERMANY

* Corresponding author 